\title{
¿Víctima o testigo del coronavirus?
}

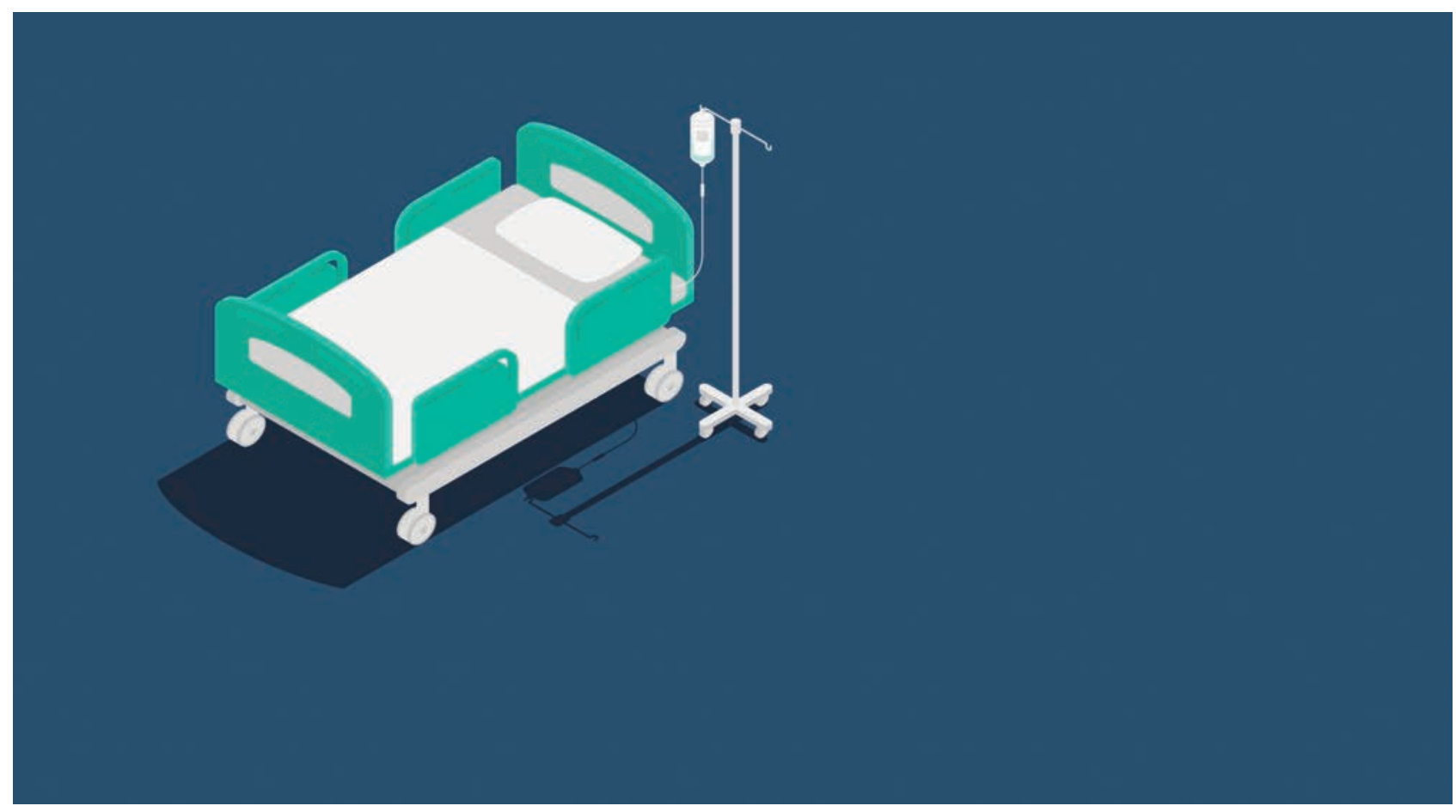

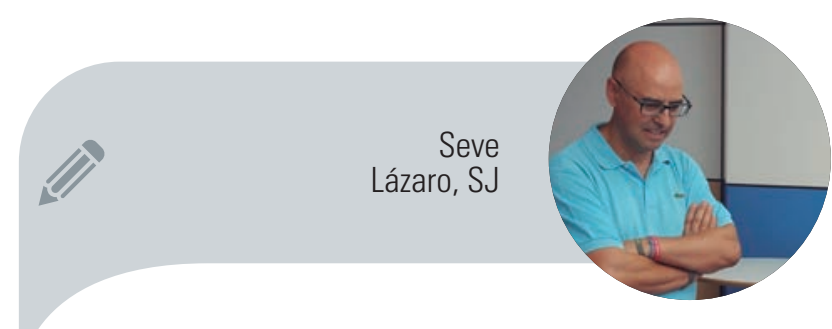

Barrio de La Ventilla (Madrid)

sblazarosj@gmail.com

Me piden que escriba unas letras sobre cómo estoy viviendo este tiempo de aislamiento. El haber sido tocado por esto del coronavirus y haber visto sus garras primero en casa y luego en el hospital, sin hacerme sentir diferente a nadie, me convierte un poco en víctima y otro poco en testigo, como muchos otros. Creo que el aprendizaje está en ir del primero al segundo.

Víctima, como tanta y tanta gente que a mi alrededor lo padece y lo sufre. Con esa incertidumbre de ver los síntomas aparecer y darme cuenta de que nada me calma, de que nada alivian esos remedios de paracetamol, ibuprofeno, Nolotil, y tantos otros calmantes. ¡Qué desesperación llegué a sentir con esa maldita fiebre que no se me iba!

Víctima, porque me sentí esquizofrénicamente desinformado de lo que realmente me pasaba. Pues los números oficiales de teléfono a los que Ilamaba nunca me cogían, o los médicos me lo negaban todo en los pasos previos al ingreso, quédate en casa, me decían, será una gripe, será un cuadro viral, bueno, te vamos a hacer unas pruebas y te vuelves a casa... Cuando por otro lado, los medios me inundaban de información con los síntomas, y día a día en mi domicilio comprobaba que eran los que yo tenía. ¡Llegué a no entender nada!

Víctima también de verme de repente marcado y señalado, como alguien al que hay que aislar inmediatamente y del que hay que prevenirse, del que hay que avisar urgentemente que lo tengo, para que todos aquellos con los que estuve en contacto se pusieran rápidamente en cuarentena. Lo que me hizo ver el rostro más amargo de esta pandemia: estoy contagiado y condenado a estar solo, apartado. Todavía resuena en mi cabeza el grito de una enfermera diciéndole a otra que se disponía a entrar en mi habitación: jen la 325 no entres por nada del mundo! Cuántas habitaciones y domicilios tienen esa marca y se les habla y mete la comida desde la puerta, o se les Ilama por teléfono una miserable vez al día desde los centros médicos, para poco a poco dejarles morir, como a Pepi, la sacristana de nuestra parroquia.

Pero esta vivencia de víctima, que tal vez es la primera, tiene que ir dejando paso a otra, la de testigo, y esta, al menos en mi caso, está siendo la vi- 


\section{Allí dentro de mí, donde hasta entonces solo existían el virus y la soledad que le acompañaba, de repente sentí que más adentro incluso, y sallándose todos los protocolos, se había melido el amor incondicional de mi madre}

vencia más profunda y más fecunda, en lo que puedo alcanzar a ver.

Testigo de ver cómo la debilidad me roza, se instala en mi vida o me llega a invadir: es muy duro vivirse ahí, durante minutos, horas, días que se hacen eternos... Pero a la vez es muy fecundo, porque toco el humus y la tierra de eso que soy realmente, un ser terrenal, finito, fragmentado... Muy lejos de ese endiosamiento y centro en el que me gusta vivir, y por el que me afano cada día desde mi pericia personal o profesional. Qué bueno que este dichoso virus esté haciéndonos sentir débiles a todos: a los especialistas, a los políticos, a los profesionales de la salud, a los familiares y, cómo no, a los enfermos. Qué oportunidad está siendo para aprender a adorar y dar gracias por el misterio de fragilidad y vulnerabilidad que envuelve esta aventura de mi vida.

Testigo de ver cómo tantas y tantas personas desde diferentes puestos hacen todo lo que pueden. Se cuenta que Van Eyck y algunos otros pintores flamencos firmaban sus cuadros con una misma frase que decía: "como mejor puedo". Y esa es la firma que todos estamos poniendo en esta cuarentena. Me gustaría estar mejor de lo que muchas veces me descubro, vivir mejor este difícil momento, sentirme más útil desde lo que voy haciendo o querría hacer... Todos estamos lejos o muy por debajo de eso por lo que tanto se nos mide en las empresas y trabajos: nuestro rendimiento profesional. Pero quién nos ha metido eso en la cabeza. Lo que la vida me pide en esta y en cualquier otra circunstancia es que haga "como mejor pueda". Y me ha parecido y es tan hermoso verlo en los cuidados de la gente de la comunidad en la que vivo, y que tan cariñosamente me atienden en el aislamiento; como en Raúl, el médico que durante esos cinco días que estuve en casa me llamaba por la mañana, por la tarde y por la noche; como en todo el equipo del hospital de Asisa en Moncloa donde estuve ingresado cinco días; como en toda esa corriente de mensajes de ánimo y ora- ción que he recibido y recibo por el teléfono; como en la sociedad entera que lo único que puede hacer es quedarse en casa y aplaudir agradecidamente todos los días a las 20.00 h. Qué gran aprendizaje este de sentirnos todos más torpes, menos eficaces, haciendo solo "como mejor podemos".

Testigo, finalmente, de lo incondicional. No tengo dudas de que esta pandemia me está obligando todos estos días a mirar de frente a ese acontecimiento al que siempre intento esquivar: la muerte. Lo veo en las cifras que cada día se van multiplicando y que ya no son cifras, sino rostros e historias de personas que quiero, cercanas a la familia, al barrio en el que vivo, al trabajo, a la parroquia de la que formo parte, a todos los ámbitos de la sociedad... En mis días de hospitalización, las cuatro noches me despertaban los gritos del paciente de la habitación de al lado, al cual, con oxígeno y todo, le venían ataques de tos que intentaban ahogarle... y yo al lado rezaba. Mi madre, que también me llamaba cada día dos veces; el martes 17 me contaba cómo el domingo 15, cuando puse por el WhatsApp familiar que me llevaban al hospital, le dijo a mi hermano (con el que vive) que la acompañara a la iglesia a rezar. Yo, sin dejarla terminar, le pregunté: "¿no le habrás pedido a Dios que me cure sí o sí?". Y ella, con su fe de 84 largos años me dijo: "no, hijo ¿cómo se te ocurre que voy a pedirle eso a Dios, si no somos nada? Solo le dije que te curaras si conviene. Y lo que luego le supliqué todo el tiempo es que donde tú fueras, que me llevara allí, contigo. Que solo junto a ti querría estar, fuera donde fuera". En esa hora, solo acerté a llorar. Pero estos días volviendo a ella, siento que ahí empezó mi mejoría. Allí dentro de mí, donde hasta entonces solo existían el virus y la soledad que le acompañaba, de repente sentí que más adentro incluso, y saltándose todos los protocolos, se había metido el amor incondicional de mi madre.

Qué bueno que esta pandemia nos esté poniendo cerca de lo incondicional de la vida que es la muerte, pero que es también el amor. Y que cuando acertamos a expresarlo, como mi madre conmigo, estoy seguro de que se revelará más fuerte y entrará más adentro que el mismo virus, hasta arrancarnos de él. Así que no dejemos de gastar en teléfono para gritar a todos los que se sienten solos y enfermos que no lo están, que hay algo más fuerte que es el amor que les tenemos •

Artículo publicado el martes 24 de marzo de 2020

https://infosj.es/vida-en-compania/16227-victima-o-testigo-delcoronavirus 